\title{
A CROSS-SECTIONAL STUDY REGARDING KNOWLEDGE ABOUT BREASTFEEDING AMONG PRIMI PREGNANT MOTHERS ATTENDING FOR ANTENATAL CHECKUP IN A MEDICAL COLLEGE, TRIPURA
}

\author{
Bappaditya Som ${ }^{1}$, Kaushik Tripura²
}

${ }^{1}$ Assistant Professor, Department of Obstetrics and Gynaecology, Tripura Medical College and Dr. BRAM Teaching Hospital, Hapania. ${ }^{2}$ Assistant Professor, Department of Community Medicine, Tripura Medical College and Dr. BRAM Teaching Hospital, Hapania.

\begin{tabular}{l}
\hline ABSTRACT \\
\hline BACKGROUND \\
Breastfeeding is an important public health strategy for improving infant and child morbidity and mortality, improving maternal \\
morbidity and helping to control health care costs. Breastfeeding is associated with a reduced risk of otitis media, gastroen teritis, \\
respiratory illness, sudden infant death syndrome, necrotising enterocolitis, obesity and hypertension.
\end{tabular}

\section{OBJECTIVE}

To assess the knowledge about breastfeeding among primi pregnant mothers attending for antenatal checkup at outdoor of Obstetrics and Gynaecology Department of Tripura Medical College, Tripura.

\section{MATERIALS AND METHODS}

This is a hospital-based cross-sectional study and was carried out in the Department of Obstetrics and Gynaecology, Tripura Medical College and Dr. BRAM Teaching Hospital, Tripura among 100 primi pregnant mothers.

\section{RESULTS}

In our study, $88 \%$ of the participants had adequate knowledge regarding breastfeeding.

\section{KEYWORD}

Breastfeeding, Cross-Sectional, Tripura, Pregnant Mothers.

HOW TO CITE THIS ARTICLE: Som B, Tripura K. A cross-sectional study regarding knowledge about breastfeeding among primi pregnant mothers attending for antenatal checkup in a medical college, Tripura. J. Evolution Med. Dent. Sci. 2016;5(81):6061-6063, DOI: $10.14260 /$ jemds/2016/1368

\section{BACKGROUND}

Breastfeeding is an important public health strategy for improving infant and child morbidity and mortality, improving maternal morbidity and helping to control health care costs. Breastfeeding is associated with a reduced risk of otitis media, gastroenteritis, respiratory illness, sudden infant death syndrome, necrotising enterocolitis, obesity and hypertension. ${ }^{1}$ The World Health Organisation (WHO) and United Nations Children's Fund (UNICEF) recommend that every infant should be exclusively breastfed for the first six months of life with breastfeeding continuing for up to two years of age or longer. ${ }^{2}$ A recent trial has shown that early initiation of breastfeeding could reduce neonatal mortality by $22 \%$, which would contribute to the achievement of the Millennium Development Goals. ${ }^{3}$ Exclusive Breastfeeding (EBF) reduces infant deaths caused by common childhood illness such as diarrhoea and pneumonia, fastens recovery during illness and helps space births. ${ }^{4}$ Studies have showed that breastfed babies are more intelligent, improves their academic performance and they become smarter than formula

Financial or Other, Competing Interest: None.

Submission 19-07-2016, Peer Review 25-09-2016,

Acceptance 03-10-2016, Published 08-10-2016.

Corresponding Author:

Dr. Bappaditya Som,

Assistant Professor,

Department of Obstetrics \& Gynaecology,

Tripura Medical College \&

Dr. BRAM Teaching Hospital,

Hapania, West Tripura-799014.

E-mail:dr.bsom@rediffmail.com

DOI: $10.14260 / j e m d s / 2016 / 1368$ fed babies. ${ }^{5}$ It is no doubt that no other food can replace mother's milk. ${ }^{6}$ Many studies done in India revealed that the knowledge of the mothers was inadequate in areas of time of initiation of breastfeeding, colostrum feeding, duration of exclusive breastfeeding and continuation of breastfeeding while baby is sick.7 There was no study conducted in our medical college to assess the knowledge of primi mothers about breastfeeding attending for antenatal check-up, therefore this study was aimed to assess the knowledge regarding breastfeeding among primi mothers attending for antenatal check-up in our institution.

\section{OBJECTIVES}

To assess the knowledge about breastfeeding among primi pregnant mothers attending for first time antenatal checkup at outdoor of Obstetrics and Gynaecology Department of Tripura Medical College, Tripura.

\section{MATERIALS AND METHODS}

This hospital-based cross-sectional study was carried out in the Department of Obstetrics and Gynaecology, Tripura Medical College and Dr. BRAM Teaching Hospital, Tripura. The duration of the study was 4 months (January 2016 to April 2016). The primi pregnant mothers attending the Outpatient Department of Obstetrics and Gynaecology for first time were recruited in the study. The sample size was calculated to 100 using $4 \mathrm{pq} / \mathrm{L}^{2}$ formula, where $\mathrm{p}$ (Prevalence) $=50 \%, \mathrm{q}=1-\mathrm{p}$ and $\mathrm{L}$ (Absolute precision $)=10 \%$. All the participants were explained about the study and written consent were taken. Any primi pregnant mother not willing to give consent were excluded. A pre-tested interview proforma were used for data collection. The proforma were translated to local language. 
The proforma were consisting of two parts, Part-I consists of information regarding socio-demographic and part-II regarding knowledge about breastfeeding. Total 10 questions were used to assess the knowledge. For each correct answer 1 (one) point and for each wrong answer 0 (zero) point were allotted. Out of total 10 points if Participant scored $\geq 6$, it is taken as having adequate knowledge and if the participants scored $<6$, it is taken as having poor knowledge regarding breastfeeding. Purposive sampling used to select the participants. The data was entered and analysed using SPSS software version 20. Results were expressed in frequency.

\section{RESULTS}

In the present study, (Table No. 1) the age of majority participants (49\%) were in less than 25 years. Majority (74\%) were from Hindu religion. Majority of the participants (43\%) and their husbands (42\%) studied up to primary level. Most of the participants were from joint family $(68 \%)$ and total monthly income were around 10,000 Rs/- (61\%). Majority of them $(95 \%)$ were housewife.

\begin{tabular}{|c|c|}
\hline Socio-Demographic Variables & Frequency $(n=100)$ \\
\hline \multicolumn{2}{|l|}{ Age (Years) } \\
\hline$\leq 25$ & 49 \\
\hline $26-30$ & 29 \\
\hline $31-35$ & 9 \\
\hline$\geq 36$ & 13 \\
\hline \multicolumn{2}{|l|}{ Religion } \\
\hline Hindu & 74 \\
\hline Muslim & 20 \\
\hline Buddhist & 5 \\
\hline Christian & 1 \\
\hline \multicolumn{2}{|l|}{ Education } \\
\hline Uneducated & 9 \\
\hline Primary & 43 \\
\hline Secondary & 33 \\
\hline Higher Secondary & 1 \\
\hline Graduate \& above & 14 \\
\hline \multicolumn{2}{|l|}{ Husband's Education } \\
\hline Uneducated & 11 \\
\hline Primary & 42 \\
\hline Secondary & 12 \\
\hline Higher secondary & 9 \\
\hline Graduate \& Above & 25 \\
\hline \multicolumn{2}{|l|}{ Occupation } \\
\hline Housewife & 95 \\
\hline Private Job & 5 \\
\hline \multicolumn{2}{|l|}{ Monthly Total Family Income } \\
\hline$\leq 10000$ & 61 \\
\hline $11000-20000$ & 26 \\
\hline $21000-30000$ & 10 \\
\hline $31000-40000$ & 00 \\
\hline $41000-50000$ & 1 \\
\hline$\geq 51000$ & 2 \\
\hline \multicolumn{2}{|l|}{ Family } \\
\hline Nuclear & 32 \\
\hline Joint & 68 \\
\hline $\begin{array}{l}\text { Table 1: Distribution of } \\
\text { according to Socio- }-\end{array}$ & $\begin{array}{l}\text { Participants } \\
\text { nography }\end{array}$ \\
\hline
\end{tabular}

In this study, majority of the participants (89\%) answered that breast milk should be given just after birth. Only $10 \%$ of the participants said honey should be given just after birth; $63 \%$ of participants said that the first feed should be given within one hour of normal vaginal delivery; $74 \%$ said colostrum should be given and $13 \%$ of the participants said colostrum should be discarded and $13 \%$ have said that they do not have any idea about colostrum. Majority (63\%) of the participants said weaning should start after 6 months. Majority (93\%) agreed that breastfeeding should be continued after 6 months; $86 \%$ of the participants said breastfeeding have additional advantage; $80 \%$ of the participants agreed that breastfeeding should be continued during sickness of the baby. About the timing of feeding, $60 \%$ of the participants said baby should feed on semi demand; $77 \%$ of the participants said no other food should be given to the baby except breast milk in first 6 months.

\begin{tabular}{|c|c|}
\hline $\begin{array}{c}\text { Knowledge Regarding } \\
\text { Breastfeeding }\end{array}$ & $\begin{array}{l}\text { Frequency } \\
(n=100)\end{array}$ \\
\hline \multicolumn{2}{|l|}{$\begin{array}{c}\text { What should be Given as a } 1^{\text {st }} \text { Feed to } \\
\text { the New Born }\end{array}$} \\
\hline Breast Milk & 89 \\
\hline Honey & 10 \\
\hline Water & 01 \\
\hline \multicolumn{2}{|l|}{ Timing for First Feed for NVD } \\
\hline With-in 1 hour & 63 \\
\hline After 1 hour & 20 \\
\hline No idea & 17 \\
\hline \multicolumn{2}{|l|}{ Colostrum Should be Given to New } \\
\hline Yes & 74 \\
\hline No & 13 \\
\hline No Idea & 13 \\
\hline \multicolumn{2}{|l|}{ Duration for Exclusive Breastfeeding } \\
\hline Less than 6 Months & 3 \\
\hline 6 Months & 69 \\
\hline More than 6 Months & 23 \\
\hline No Idea & 5 \\
\hline \multicolumn{2}{|l|}{ Timing for Weaning } \\
\hline Before 6 months & 12 \\
\hline 6 months & 17 \\
\hline After 6 months & 63 \\
\hline No Idea & 8 \\
\hline \multicolumn{2}{|l|}{ Breastfeeding Should Continue After 6} \\
\hline Yes & 93 \\
\hline No & 2 \\
\hline No Idea & 5 \\
\hline \multicolumn{2}{|l|}{ Breast Milk Have Additional } \\
\hline Yes & 86 \\
\hline No & 5 \\
\hline No Idea & 9 \\
\hline \multicolumn{2}{|l|}{ Breastfeeding Should Continue During } \\
\hline Yes & 80 \\
\hline No & 13 \\
\hline No Idea & 7 \\
\hline \multicolumn{2}{|l|}{ Timing for Breastfeeding } \\
\hline When Baby Cries & 27 \\
\hline Fixed Timing & 13 \\
\hline Semi Demand & 60 \\
\hline \multicolumn{2}{|l|}{ Others Food Can Be Given Before 6} \\
\hline Yes & 15 \\
\hline No & 77 \\
\hline No Idea & 8 \\
\hline
\end{tabular}

In the present study (Table 3), it was observed that majority $(88 \%)$ of the participants were having adequate knowledge about breastfeeding. 


\begin{tabular}{|c|c|}
\hline Level of Knowledge & Frequency \\
\hline Adequate Knowledge & 88 \\
Poor Knowledge & 12 \\
\hline \multicolumn{2}{|c|}{ Table 3: Level of Knowledge regarding } \\
Breastfeeding among Participants \\
\hline
\end{tabular}

\section{DISCUSSION}

In the present study, it was observed that $89 \%$ of the participants knew that breast milk should be given as $1^{\text {st }}$ feed to the new born; $63 \%$ of the participants in our study knew that $1^{\text {st }}$ feeding to the new born should be started within 1 hour. Similar result has been seen with other studies.8,9 But study done in West Bengal10 showed only $37.3 \%$ have knowledge that $1^{\text {st }}$ feeding should be given within 1 hour. Majority (74\%) of the participants in our study knows that colostrum should be given to the new born. Similar result observed in a study conducted in Mangalore. ${ }^{8}$ At present study, $69 \%$ of the participants said that exclusive breastfeeding should be continued up to 6 months. At other studies, it is ranged from $28 \%$ to $71.6 \% .8,90 \%$ of the participants in our study said breastfeeding should be continued during sickness of the baby and similar result has been observed in other study. 10 Only $27 \%$ of our study participants said baby should put on demand feeding like other study. ${ }^{11}$ In our study $88 \%$ of the participants had adequate knowledge regarding breastfeeding, but in other studies is ranged from $23 \%$ to $96.4 \% .^{10,12}$

\section{REFERENCES}

1. James DC, Lessen R, American Dietic Association. Position of the American dietetic association: promoting and supporting breastfeeding. J Am Diet Assoc 2009; 109(11)):1926-42.

2. WHO and UNICEF. Global strategy for infant and young child feeding. World Health Organization, Geneva, 2003.
3. Edmond KM, Zandoh C, Quigley MA, et al. Delayed breastfeeding initiation increases risk of neonatal mortality. Pediatrics 2006;117(3):380-6.

4. Exclusive breast feeding recommendations. http://rehydrate.org/breastfeed/faqexclusivebreastfeed ing.Htm.

5. Lucas A, Morley R, Cole TJ, et al. Breast milk and subsequent IQ in children born preterm. Lancet 1992;339(8788):261-4.

6. Smith LG. Breastfeeding and bottle feeding. Journal of Tropical Pediatrics 2000;32(2):407-15.

7. Ekambaram M, Bhat V, Ahamed MAP. Knowledge, attitude and practice of breastfeeding among postnatal mothers. Curr Pediatr Res 2010;14(2):119-24.

8. Shetty SB, Shetty SK. KAP study of factors promoting breastfeeding in nursing mothers and pregnant women. NUJHS 2013;3(3):34-7.

9. Noor S, Rajesh AH, Babu GK. A study on breast feeding practices among mothers of urban slums of Rourkela. IOSR Journal of Dental and Medical Sciences 2015;14(5):77-80.

10. Ray D, Rahaman A, Dasgupta A. Breastfeeding knowledge among antenatal mothers: a cross-sectional study in a rural area of West Bengal. IOSR Journal of Dental and Medical Sciences 2015;14(5):93-97.

11. Harnagle R, Chawla PS. Study of knowledge, attitude and practices of lactating mothers on breast feeding, weaning immunization and dietary practices at Jabalpur cantonment. India Int J Curr Microbiol App Sci 2013;2(11): 393-403.

12. Simon MC, Sebastian NM, Alex N, et al. Knowledge regarding breast feeding among primi mothers in a selected hospital of Bangalore, Karnataka. American International Journal of Research in Humanities, Arts and Social Sciences 2014;8(1):87-91. 